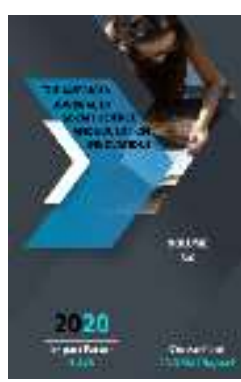

Journal Website: http://usajournalshub.c om/index,php/tajssei

Copyright: Original content from this work may be used under the terms of the creative commons attributes 4.0 licence.

\section{The Linguistic Picture Of The World, Embodied In The Chinese And Russian Idioms Of Animals}

\author{
Li Hujun \\ Independent Researcher, Department Of “Chinese Philology” Tashkent State University Of \\ Oriental Studies, Uzbekistan \\ Sabokhat Abdullaevna Khashimova \\ Doctor Of Philology, Associate Professor, Scientific Supervisor, Department Of "Chinese \\ Philology", Tashkent State University Of Oriental Studies, Uzbekistan
}

\title{
ABSTRACT
}

The linguistic map of the world is a set of achievements in the knowledge of the world by the nation, which is fixed in the language in the process of the development of the language and the nation. Animals always accompany people in production and life. And in every language, a large number of idioms associated with animals have accumulated. These idioms not only reflect each nation's understanding of the animals themselves, but also reflect the wider world of language. This article made an attempt to explain the meaning of animal idioms in the Chinese and Russian languages, and also analyzed the universal linguistic picture of the world and the national linguistic picture of the world in China and Russia.

\section{KEYWORDS}

Linguistic picture of the world, idiom, metaphor, phraseological unit, myth, cognitive science, universality, scientific picture of the world.

\section{INTRODUCTION}

The study of the linguistic picture of the world dates back to the beginning of the 19th century, when W. Von Humboldt formulated the idea of the existence of a special linguistic worldview as a scientific and philosophical problem. In Humboldt believed that "language as a tool for the thoughts and feelings of the people plays a decisive role in establishing" [ 2, p. 377] "Natural language reflects its own way of perception and organization of the world. Its meanings form a single system of views, which is mandatory for all native 
speakers and is called the linguistic picture of the world. It is "naive" in the sense that it often differs from the "scientific" picture of the world. At the same time, the naive ideas reflected in the language are by no means primitive: in many cases they are no less complicated and interesting than scientific ones" [1, p.262].

\section{THE MAIN FINDINGS AND RESULTS}

Chinese scholars Wu Guohua and Yang Xichang put forward the following proposals in 2000: "the linguistic picture of the world is a concentrated expression of the nation's understanding for the real world in language. [4. $p, 45]$ Summing up, we can assume that the language map of the world is a set of achievements in the knowledge of the world by the nation, which is fixed in the language in the process of development of the language and the nation. As a fixed linguistic unit that has been accumulated and passed down from generation to generation, idioms reflect the peculiarities of ethnic history, culture, lifestyle, worldview and values of nations. It has long symbolized the knowledge and understanding of the world by people, shows the rich content of the national linguistic picture of the world. According to statistics "School phraseological dictionary of the Russian language" (1994) "Dictionary of Russian idioms for secondary schools" has 113 idioms containing the names of animals, including 36 animals. [3. p, 12] Animals that are often found in Russian idioms are chickens, sheep, horses, dogs, cats, fish, cows, birds and other domestic animals, poultry and domestic animals.

\section{DISCUSSION AND RESULTS}

According to statistics from "The Dictionary of Chinese Idioms" (2007), [5.c, 118] published by the Shanghai Lexicographic Publishing House, we have collected 875 idioms related to animals.

1. A universal linguistic picture of the world, embodied in the Chinese and Russian idioms of animals.
(1) Animal idioms reflecting ethics and values. Respect for the elderly, ridicule of ignorance:

In Russian idioms "An old horse will not spoil the furrow” (老马不会踩坏垄沟,) expressing the veteran is not mistaken. "You cannot deceive the old sparrow on the chaff" (谷糠 骗不来老麻雀) denoting experienced people it is not easy to deceive. "Put a fox in a chicken coop” (把 狐狸放进鸡窝), “comes like a giraffe" (理解东西就像声音传到长颈 鹿长脖子上的耳朵一样慢), expressing mockery of the lack of wisdom. In Chinese, “老 马识途” (old horse knows the way) means experienced person is more familiar with things. “呆若木鸡” (Stupid like a wooden chicken) describes a person with low intelligence and “蚌如鹿豕” (stupid like a boar deer) means as stupid as a deer and a pig.

Hate of hypocrisy and lies, I criticize flattery: “a crow in peacock feathers” (孔雀羽毛下的 乌鸦), expressing a peephole, covered with a beautiful fur coat. "A wolf in sheep's clothing" (披着羊皮的狼) expressing a hypocrite. “To pretend to be a fox" (假装狐狸) expresses sycophancy. There are many similar idioms in Chinese, such as "狐假虎威"（hu jia hu wei）, which means to rely on the power of others to intimidate someone. “披着羊皮的狼”（wolf in sheep's clothing), expressing a hypocrite. “ 佛口蛇心”（the heart of the snake from the mouth of the Buddha) means the words are good, but the heart is extremely evil. "猪卑狗 脸" (face of a pig, bee, dog) expresses a mean and sinister person), etc.

Be grateful, ironic greed: “They don't look a gift horse in the mouth”（的的马不看牙口 ) expressing not picky about the gift. "To fall like a wolf before falling" （像狼渴望尸体那样 拼命追求) desperately like a wolf looking for 
a corpse. Chinese has idioms like “狼贪虎视” It means to be greedy like a wolf, and to look with wide eyes like a tiger, metaphorically expressing greed. “狼心狗肺” Describes a person who is dangerous, vicious, or ungrateful. "蛇欲吞象" The snake wanted to swallow the elephant, expressing great greed.

Glorification of labor, ridicule of laziness: The wolf's feet are fed. work like an ox. count the crows. get drunk / get drunk like a pig. In the Chinese language there are "汗马功劳", which means to establish feats of arms on the battlefield. Now refers to the contribution of hard work. "俯首甘为 孺子牛" The original meaning is to bend over to people, to be their cattle and horses. Now it is designated willingly to serve the people. "狐朋狗友" stands for parasitic friends.

Glorification of labor, ridicule of laziness: The wolf's legs are fed, work like an ox, count crows, get drunk / get drunk like a pig. In the Chinese language there are "汗马功劳", which means to establish feats of arms on the battlefield. Now refers to the contribution of hard work. "俯首甘为 孺子牛" The original meaning is to bend over to people, to be their cattle and horses. Now it is designated willingly to serve the people. "狐朋狗友" stands for parasitic friends.

Praise for bravery, irony for cowardice: when describing a brave person, Russians probably use the image of "lion" as an analogy, and the Chinese "tiger" as a metaphor. The Russians say "Brave lion" "to fight like a lion", the Chinese say “一身 虎胆” a man with tiger courage. "猛虎 下山" is as powerful as a tiger from a mountain. "如虎添翼" means to make the strong one stronger, as if the tiger had grown wings.

(2) The metaphor of idioms with animal words reflects the understanding of people for themselves and animals. Metaphor is the juxtaposition of one kind of thing to another.
Using the understanding of known things, measuring the characteristics of unknown things. It is the embodiment of national culture and cognitive methods. Animals have lived with people for a long time, so people often compare them with people. Animal metaphorical idioms typically use animal imagery to describe the character, behavior, and condition of humans.

Description of the external characteristics of people using the external characteristics of animals: Similar idioms in Russian: red as cancer (像 螃蟹一样 面红耳赤); healthy / strong as a bull (健壮如牛); dirty as a pig（ 脏 得像 猪). In Chinese, "虎背熊腰" (the back is tiger and the waist is bearish), denoting that the back is wide, like a tiger, and the waist is like a bear. Describes a large and strong person; "虎头虎脑" （tiger head tiger brain) describes a strong and good-natured appearance (more referring to boys); "龙眉 凤 眼" (dragon eyebrows and phoenix eyes) describes human eyes are very beautiful and very cute; “龟年鹤寿” means that turtles and cranes have thousands of years of life, and they are used to express human longevity.

Description of the characteristics of human behavior with the characteristics of animal behavior: In the Russian language there are: agile as a monkey（猴子 般灵活）; quirky like

（灵活如蛇）; clumsy as a bear（像熊一样 笨拙）; laughs like a horse（像马嘶鸣一样 粗鲁地大笑）. And in Chinese: "静若处子， 动若 脱 兔" denoting when the army is stationary, it is calm and cautious like an unmarried girl, and when it attacks, it must be nimble and fast like a flying rabbit. "身轻如燕"

(the body is light as a swallow) denoting a person is able to Gun Fu, moves quickly and easily; "花飞蝶舞" (flowers and butterflies dance and fly in the wind) Figuratively 
snatching, the young woman's walking is soft and light; “莺声燕语” means the words of the swallows, the singing of the oriole, describing the voice of young women talking and laughing; “河东狮吼”（Roar of a lion east of the Yellow River) meaning jealous wife quarrels with her husband; "龙行 虎步"（ drogon walk and tiger step) meaning originally the emperor's manner is great, now also describing the heroic behavior of the general.

\section{Description of the characteristics of people with the characteristics of animals:}

In Russian there are: Delicate like a lamb (像 羊 羔一样 温柔); Stuffed like sardines (跟沙丁鱼 一样 俊); Talkative like a magpie (像 喜鹊 一样 多嘴). And in Chinese: "蛇蝎 心肠" (snake and scorpion hearts) expressing a wicked person; "狼子野心" (although the cub is young, it has a ferocious disposition) expressing that violent people have an evil heart and their habits are difficult to change; " 搂狼虎豹" (jackal, tiger and leopard) expressing evil people and enemies.

2. National linguistic picture of the world, embodied in Chinese and Russian idioms with the words of animals. Since ancient times, animals have been closely associated with humans. They have played an important role in the production and life of humans and have contributed greatly to the prosperity of mankind. Within the framework of long-term relationships, people gradually acquired a deep understanding of the various images and habits of animals, realized the similarities between them and humans. relying on their own knowledge and the ability to reason, they gave animals a certain metaphor to explain or describe the meaning of ontology. After analyzing the results of the previous study, we believe that the natural and geographical environment of China and Russia, their national cultural roots, as well as some characteristics of the Russian and Chinese languages have an important influence on the formation of differences between Russian-Chinese metaphors with the words of animals.

1) Idioms with animal words reflect the environment:. The language and culture of a nation grows and develops in a specific natural environment. Geographic conditions, climatic conditions, animal and plant resources and associated agricultural production methods not only affect the material life of people, but also affect the spiritual life of people and leave a mark on the language. Take the tiger, for example: there are many idioms about the tiger in Chinese, but very few in Russian. According to textual studies, the most primitive tiger is produced in China, and the oldest of the nine modern subspecies is the South China tiger. Two million years ago, the South Chinese tiger lived on the land of China and had countless "close" encounters with the ancient Chinese. Through the process of longterm contact, the Chinese people deeply understand tigers and are full of awe and worship, gradually forming a unique tiger culture. The tiger is considered the most powerful protector of the ancestors of mankind, and has been given the characteristic functions of suppressing ghosts and fighting disasters, casting out evil and avoiding evil spirits, bestowing blessings and blessing homes. Moreover, the image of the tiger is not only powerful but also colorful. In the center of the forehead, there is an inborn character "king", which produces a visually shocking effect, which is why the Chinese praise him as the "King of beasts".

In Russia, tigers are rare and difficult to touch animals. Only one subspecies of tigers lives in Russia - the Amur tiger, which is mainly distributed in the taiga forests of the Far East. And since the later development of Russia was in the lead in the Far East, Russians only recently learned about tigers. As a rare species peculiar only to the Far East, the tiger did not play a big role in the everyday life of Russians. Therefore, although his image entered the 
space of traditional Russian culture, he did not receive wide distribution and development, as the image of a "tiger" in Chinese culture. In the Russian language there are many idioms associated with wild animals such as wolves, bears, foxes, etc. The bear lives in deep mountains and old forests, so the "bear's corner" represents a poor and distant province; "Even a wolf howl" (in a hopeless position), "wolf mouth, fox tail" (coincidence with the Chinese idiom 笑里藏刀); "From the wolf, to the bear hit" (Running away from the wolf and bumping into the bear again), corresponding to 刚出 龙潭又入虎穴（just running away from the dragon and entered the tiger's lair). These animals are also widely used as metaphors for idioms in China, but compared to the number of idioms; the Han nation loves tigers more.

2) Idioms with animal words reflect religious beliefs. In 988, Grand Duke Vladimir adopted the Orthodox faith, laying the foundation for Russian thinking for more than a thousand years. During the spread of the Orthodox Church, many idioms entered the Russian language from Church Slavonic, "the scapegoat" (from the "Bible • Old Testament"), "Throwing pearls before pigs" from the Bible - New Testament In the Gospel of Matthew it is written: "Do not pass on a sacred object the dog and do not throw the pearl in front of the pig. I am afraid she will trample the pearl and turn to bite you. Now people use this idiom to describe someone telling an incomprehensible truth. "Eating Acrid and Wild Honey" describes food shortage and hunger. From the biblical story: John the Baptist was starving in the wilderness, satisfying his hunger with locusts and the wild. Previously, Russian churches did not store food or provide food, and the clergy refused to accept earthly riches. In this case, rats have nothing to steal from the church. "Poor as a church" depicts the state of people who are poor and cannot guarantee their own life. Various religions from ancient times have allowed pigeons to build nests in temples.
During the period of polytheism, the dove was the personification of peace, purity, love and innocence in Christianity; it was often dedicated to the highest gods. On the land of Russia there is a saying: "Even a dove does not fly to an unkind person". Swallows and pigeons belong to the genus of the larynx, belong to the genus Song and are pure birds in the eyes of the Slavs. so there is "The dove and the swallow - the beloved birds of God." Like the Russian language, the Chinese language in its historical development was influenced by various religions and cultures, among which the Buddhist culture had the greatest influence. Buddhism in ancient India, which originated in the 6th century BC, was introduced to China during the Eastern Han Dynasty and spread rapidly. Since its dissemination process is mainly based on Buddhist canons, many Buddhist classics have been translated into Chinese since the end of the Eastern Han Dynasty. The vocabulary of Buddhism penetrates deeply into the people and penetrates widely into all spheres of Chinese society. Lion's Roar comes from the classic Buddhist Vimalain Sutra - Fo Guoping. This word expresses the speech of the Buddha when he makes a loud noise and shakes the world. Today, “河东狮吼” is often used to describe the curse of a grumpy woman. In addition, some of the animal metaphors in Chinese come from Confucianism. For example, “对牛弹琴” (play the piano for the cow.

Another religious culture that has had some influence on the metaphor of Chinese animals is Taoism. Taoism is a religion that originated and developed in China based on the Taoist ideas of Laozi and Zhuangzi, and has a history of more than 1800 years. “仙风鹤骨”（ celestial monera and crane bone) describing the energy and strength of a person is not as common as a celestial; “孤云 野鹤” (lonely cloud and wild crane), it means soaring clouds floating alone in the sky, cranes roaming freely 
in the sky; used to refer to people who are idle and do not strive for fame and fortune. “鹤发 童颜" means white hair like the fluffy feathers of a crane and a ruddy complexion like a child, describing the beauty and health of the elderly. It is obvious that the different religious beliefs preached by the Russian and Chinese peoples are one of the main factors influencing the formation of the difference between Russian and Chinese metaphors with the words of animals. As an integral part of Russian and Chinese national culture, religion, on the one hand, is deeply imprinted in the minds of people and limits and influences the development of metaphorical language, and on the other hand, it enriches the cultural symbolic meaning of some animal words. Therefore, under the influence of different religious cultures, the same animal words are often given different meanings in Russian and Chinese languages, and they form unique animal metaphors, deeply immersed in religion.

(3) Idioms with animal words reflect traditional ideas and folk myths. The connection between animal metaphors and folk myths and legends is also close and unusual. As the national culture and wisdom crystallize, myths, legends and folk tales can persist in the subconscious of members of the nation for a long time and deeply influence their psychology and way of thinking. In Chinese myths and legends, the dragon is the head of all animals and a symbol of power, nobility and honor. The ancestors of the Chinese nation, Emperor Yang and Emperor, are said to have been closely associated with dragons. From ancient times to the present, the dragon, as a mythical animal, has the highest status among the Chinese. He is a symbol of wealth, favor, luck and success. He personifies the aspirations of the Chinese people for a better life and is deeply loved by people. This special emotion towards dragons is embodied in a unique metaphorical expression at the linguistic level. For example, in Chinese, there are many idioms associated with coincidence: “龙马 精神” (dragon horse spirit) refers to the energetic spirit of a person; “龙腾虎跃” (dragon flight and tiger jump) describes energetic movements and accomplishments; “生龙活虎” (alive like a dragon, alive like a tiger) means lively, energetic and full of energy, etc. In Russian myths and legends, you can also find mysterious animals similar to dragons, which are popularly called "Dragon". According to the legend, the mountain serpent is a monster that can summon fire, thunder, lightning and storms. It has three heads and a pair of bat-like wings and can fly and breathe fire. As the embodiment of "evil spirits" the Dragon makes ordinary Russians shudder and suffer.

\section{CONCLUSION}

The linguistic picture of the world is recorded in various linguistic units in the form of knowledge. Idioms are a summary of the life experience of people; it is the precipitation and crystallization of the history and culture of a nation, as well as a unique linguistic picture of the world of this nation. Animals have been with humans for generations. Animal idioms are used to refer to people, praise beauty and expose evil, reflecting the ethics and values of their people. It also reflects environmental characteristics, religious influences, traditional thought and culture, and ways of thinking.

\section{REFERENCES}

1. Apresyan Yu. D. Selected Works. Integral description of the language and systemic lexicography. lexic description of the language. - $M$.

2. V. Humboldt Language and philosophy of culture. - M., 1985. (Humboldt W. (1985) Language and philosophy of culture. Moscow)

3. Cui Xiaoxi. Comparative analysis of idioms containing animal names in Russian and Chinese [D]. Northeast Forestry University, 
The American Journal of Social Science and Education Innovations (ISSN - 2689-100x)

Published: November 30, 2020 | Pages: 478-484

Doi: https://doi.org/10.37547/tajssei/Volumeo2Issue11-81

2020: $5 \cdot 525$

2012.

4. Wu Guohua, Yang Xichang. Cultural Semantics [M]. Military Yiwen Publishing House, 2000.

5. Dictionary of Chinese Idioms. - Beijing, 2007 (Dictionary of Chinese Idioms.-Beijing, 2007)

6. Online version of T.F. Efremov Detailed Dictionary [EB / OL]. 